\title{
SPECIAL SECTION ON ASIAN RESEARCH
}

\author{
Guest Edited by Dr. Robert Shumer
}

Service-learning has been around in the United States since the 1960s. It has grown and spread around the world to many countries. This section is devoted to capturing some of the research and service-learning activities across Asia, with the hope of demonstrating the kind and caliber of work that is being done in that part of the world.

Despite the fact that service-learning's modern history began in the United States, its traditions and concepts date back centuries. Some suggest that the writings/teachings of Confucius actually capture many of the ideas and constructs embodied by service-learning theory and practice. Confucius had five ethical/moral principles that describe what human interaction and the goals of citizen development are all about. They were:

- Ren (仁) refers to empathy and benevolence; kindness and politeness are a way of interacting with others. This is an obligation of altruism and humaneness toward others. Everyone needs to be taught.

- $\mathrm{Li}$ (禮) involves acting respectfully, with a level of humility.

- Yi (義) is based on the idea of reciprocity; may simply mean what is ethically best to do in a certain context.

- Xin (信) means to act in ways that are not hurtful to others; be mindful of how you interact with others, both in mind and action.

- Zhi (智) refers to knowledge. Learning and knowledge were an integral part of growing in life and learning to be a responsible member of society. Must use knowledge to gain wisdom during your life to make change.

Zhi (智) suggests that the growth of children into adulthood involves learning the knowledge and skills necessary to be a "responsible member of society." This implies that the learning process involves understanding how society functions and knowing how to make changes for improvement and increased effectiveness. The ultimate goal in life is to gain wisdom ... to learn how knowledge is applied so as to affect the real world. In many ways, this is the essence of service-learning.

A historical understanding of service-learning in Asia includes the cooperation and collaboration between Western countries, especially the United States, and Asia. Famous American philosopher John Dewey did work in Japan and China and actually taught in China during the early twentieth century (1919-1921). Dewey was known in China as the "second Confucius." Several scholars from China worked with Dewey and others during the 1930s, and individuals from Japan also connected before World War II. With the development of the China Youth League (initially the Socialist Youth League of China) in the early 1920s, efforts were developed 
to engage young people in service and vocational development to contribute to their overall growth as responsible members of society. Similar organizations were developed in other Asian countries.

This cooperation and collaboration has continued into modern times. Pioneers/leaders from the United States have partnered and collaborated with Asian countries and programs. Timothy Stanton, Dwight Giles, Jane Permaul, Robert Bringle, Cathy Berger Kaye, Andrew Furco, myself, and others have been presenting at Asian conferences, assisting with research efforts, and providing support in Singapore, China, Indonesia, Japan, South Korea, and several other countries. In return, Asian scholars and practitioners have been connecting through the International Association for Research on Service-Learning and Community Engagement (IARSLCE), the National Service-Learning conference, and other conferences and meetings. Carol Ma, who has worked in Hong Kong and Singapore, completed a Chan Fellowship at UCLA in California and later became a board member for IARSLCE. Asian scholars have published articles in journals such as the Asian Pacific Journal of Education with colleagues from the United States.

There are other organizations that foster collaboration between the East and West. The Asian Society, founded in 1956, was established to promote better understanding between the United States and Asian countries. The Talloires Network, which links universities around the world, has worked with Asia Engage to promote expansion of civic initiatives in the Asian community to promote better cultural understanding and exchanges between educators. And for the service-learning world, the United Board, with current offices in New York and Hong Kong, helped to promote programs in higher education and provided some initial funding for the Service-Learning Asia Network in order to spread the research and practice of civic engagement throughout the Asian community. Currently, the Service-Learning Asia Network is convening its 7th bi-annual conference in Singapore in 2019 and connects 11 countries around the development and expansion of service-learning efforts.

Hopefully these connections and collaborations will continue for the improvement of both areas. As research and programs become more prevalent in Asian countries, there will be a greater sharing of knowledge and expertise between the two regions, and hopefully it will continue to spread to efforts around the world. There are strong international initiatives in Europe and South America, and several others are developing. The appearance of articles in this journal is another effort to formalize the knowledge sharing between the West and Asia, as well as between Asia and the whole world.

The articles in this special section cover a variety of topics and issues. Having received submissions from seven Asian countries, the information shared here represents some of the best efforts in Asia to gather research and information about service-learning practice. While there were many excellent articles submitted, reviewers recommended the four following articles for inclusion in the current edition of the Michigan Journal of Community Service Learning, ensuring that there was the broadest representation from the different countries. Several of the other articles that received good ratings but are not published here will hopefully be available in a new book to be released at a future date. The articles represented a range of research approaches, from those with positivist orientations, to mostly qualitative designs, and then several with mixed formats. The research 
work in many Asian countries varies in length of effort and development of quality outcomes. The Asia community, for the most part, is expanding, increasing, and improving its research on service-learning at all levels.

We start the special section with an article from Hong Kong by Robin Snell, Maureen Yin-lee Chan, Crystal Xinru Wu, and Constance Wing-yee Chan on "Service Leadership Emergence Through Service-Learning Internships in Hong Kong." In this article we learn of a summer internship program that seeks to develop service leadership attributes through service-learning initiatives. The research highlights data collection from students and community partners and demonstrates how the research helped to actually inform program design and development.

Next we include an article from Singapore by multiple authors Juliet Choo, Yew Kong Tan, Faith Ong, Shiuan Tiong, Sangeeta Nair, Jean Ong, and Angel Chan titled "What Works in Service-Learning? Achieving Civic Outcomes, Academic Connection, Career Preparation and Personal Growth in Students at Ngee Ann Polytechnic." Using a mixed methods design, the study investigated the impact of service-learning on students' civic and academic learning, personal growth, and career preparation at the School of Humanities \& Social Sciences. Several strong impacts were noted in areas of study demonstrating the value and change produced by service-learning efforts.

The third presentation is from Shantou University in China, by Xiangling Liu and Muqiang Zheng. Titled "The Importance of Academics: Feedback from Students of Service-Learning Curriculum," this article reports on data collected from 2011 to 2018 on service-learning courses by academics teaching in their field, academics teaching out of their disciplines, and non-academic faculty (counselors). The results indicate the importance of direct academic connections in terms of quality outcomes.

The fourth article is by Listia Natadjiaja and Elisabeth Christine Yuwono of Petra Christian University in Indonesia. They focused on "Enhancing the Learning of Packaging Design through Service-Learning Programs." In this study, the authors compared their package design classes that were taught through a traditional format with those taught using service-learning pedagogies. They collected data through student reflections and interviews and discovered the enhanced power of the service-learning approaches through experiential learning and the additional learning of civic knowledge and personal commitment to community improvement.

Hopefully these articles will provide a sense of the quality and diversity of studies currently being conducted in Asia and encourage all of us to continue the collaboration and sharing of work to help advance the field of service-learning research. We look forward to your response to this work and to your continued efforts to expand our knowledge and skills in addressing community and university needs through service-learning pedagogy.

\section{Author}

DR. ROBERT SHUMER (drrdsminn@msn.com) has been involved in education for 50 years. He has taught 
from middle school through graduate school and conducted research in many areas, from service-learning, to teacher education, to character education, to career and technical education, to civic engagement, to participatory evaluation. He served as the founding Director of the National Service-Learning Clearinghouse at the University of Minnesota and Internal Evaluator for the National Research Center for Career and Technical Education (NRCCTE). He also served as Director of Field Studies at the University of California, Los Angeles (UCLA), Vice Chair of the International Association for Research on Service Learning and Community Engagement, and President of the Minnesota Evaluation Association. He has conducted numerous evaluation studies, including a five five-year study of AmeriCorps in Minnesota, a three-year study of service learning in both Pennsylvania and Minnesota, and a six-year study of teacher education in New Jersey. He has published more than 85 articles, numerous book chapters, and even a few books on service-learning, youth-led participatory evaluation, career and technical education, teacher education, and community-based learning. He has also taught courses and consulted in many places around the world, including Mexico, Germany, England, Ireland, Morocco, Canada, Japan, Hong Kong, Taiwan, Singapore, and China.

He received his Master's in Educational Psychology from California State University, Northridge, and his $\mathrm{PhD}$ in Education from UCLA. 